\title{
The efficacy of a hemostatic agent in anticoagulant drug-induced rat bleeding model
}

\author{
Ertan Sönmez, M.D., ${ }^{1}$ Umut Yücel Çavuş, M.D., ${ }^{3}$ Cemil Civelek, M.D., ${ }^{1}$ Ali Dur, M.D., ${ }^{1}$ \\ Eda Karayel, M.D.,, ${ }^{1}$ Bedia Gülen, M.D., ${ }^{1}$ Ömer Uysal, M.D., ${ }^{2}$ Göktürk İpek, M.D. ${ }^{4}$ \\ ${ }^{1}$ Department of Emergency Medicine, Bezmialem Vakıf University Faculty of Medicine, Istanbul; \\ ${ }^{2}$ Department of Biostatistics, Bezmialem Vakıf University Faculty of Medicine, Istanbul; \\ ${ }^{3}$ Department of Emergency Medicine, Dışkapı Yıldırım Beyazıt Training and Research Hospital, Ankara; \\ ${ }^{4}$ Department of Cardiology, Siyami Ersek Training and Research Hospital, Istanbul
}

ABSTRACT

BACKGROUND: Bleeding is a major problem in warfarin pretreated patients who need emergency surgical procedures. APH is a hemostatic agent with ultra-hydrophilic and particulate properties. This study aimed to evaluate the in vivo hemostatic effect of APH in rats pretreated with warfarin.

METHODS: Forty-eight Wistar rats were divided into two main groups: one group was pretreated with warfarin and the other group was not. These two groups were further divided into three subgroups according to the administration of APH, wheat meal, or saline, for a total of six subgroups. Standard full thickness tissue defects were performed on the backs of the rats. Saline, wheat meal, or APH were administered to the bleeding defect site in both main groups. Hemostasis time and amount of bleeding were calculated.

RESULTS: The bleeding time in rats administered APH was significantly shorter than those administered wheat meal and saline. Consequently, the amount of bleeding was significantly less in the APH groups than in the control groups.

CONCLUSION: APH has an effective hemostatic property in rats pretreated or non-pretreated with anticoagulants. Hemostatic agents can be useful for incidences of external bleedings, which are increasing because of anticoagulation.

Key words: Hemostatic; rat; warfarin.

\section{INTRODUCTION}

Warfarin is an anticoagulant that reduces the effects of vitamin $\mathrm{K}$ dependent factors, and its effects are increased by many drugs. ${ }^{[I]}$ Interruption of therapy for surgical intervention increases the risk of thromboembolism, although continuation of therapy increases the risk of bleeding in patients taking warfarin. The most preferred method for stabilization in major surgical interventions is discontinuation of oral warfarin therapy and temporarily taking up to parenteral LMWH. After surgery, warfarin is reintroduced. If warfarin

\footnotetext{
Address for correspondence: Ertan Sönmez, M.D.

Bezmialem Vakıf Üniversitesi,

Adnan Menderes Bulvarı (Vatan Cad.), 34093 Fatih, İstanbul, Turkey

Tel: +90 212 - 5232288 E-mail: ertansonmez3@msn.com

Qucik Response Code Ulus Travma Acil Cerr Derg

20।4:20(2):79-85

doi: $10.5505 /$ tjtes.20I4.54938

Copyright 2014

TJTES
}

treatment is stopped before surgery, the risk of thrombosis and the consequences of thrombosis need to be carefully considered. The reduction of this risk with bridge therapy with treatment dose LMWH or unfractionated heparin in the pre-operative and post-operative periods should also be well-evaluated. ${ }^{[2]}$

An alternative option is the administration of intravenous vitamin $\mathrm{K}$ the day prior to surgical intervention. However, this method is used principally in the management of warfarin overdose, and studies about its usage in such cases are retrospective and heterogenous. ${ }^{[3]}$ Although these methods are not definitive solutions, they are principally used in elective major surgery.

In some minor surgical procedures such as joint injections, ${ }^{[4]}$ cataracts, ${ }^{[5]}$ and certain endoscopic procedures (including mucosal biopsy), ${ }^{[6]}$ continuation of warfarin therapy is considered. However, the generally-preferred method in plastic surgery, dermatology, and minor or invasive surgical interventions in emergency medicine is to take measures to stop bleeding without changing the anticoagulant therapy. 
External bleeding episodes due to warfarin are not limited to tissue defects secondary to any surgical procedure or trauma. Warfarin can cause various bleeding episodes that are clinically insignificant, but cause discomfort for patients, such as gingival bleeding after tooth brushing, epistaxis, and skin bleeding after shaving. Patients should be informed on such possible bleedings before starting these drugs. ${ }^{[3]}$ These kinds of bleeding episodes are not life-threating, but hemostasis can often be bothering. Likewise, excessive bleeding in some patients during minor surgery and long episode of leakage in the postoperative period can lead to increased anxiety in surgeons and patients, respectively.

Long-term use of surgical tampons for bleeding control can cause discomfort in patients. Some clinicians use hemostatic agents as an alternative supportive therapy in cases requiring emergency surgery and traumatic bleeding. Since hemostasis can generally be provided with simple methods, and hemostatic agents bring extra costs, clinicians hold themselves back from prescribing such agents. Several hemostatic agents with different compositions are currently available that achieve hemostasis in different ways. Some provide primary hemostasis, whereas some stimulate fibrin formation or inhibit fibrinolysis. ${ }^{[7]}$ Absorbable hemospheres produced by microporous polysaccharide hemospheres (MPH) technology were first used as a topical bleeding stopper. They were used to control bleeding wounds including traumatic wounds, cuts, and military wounds. ${ }^{[8]}$

$\mathrm{APH}$ is a hemostatic agent with ultra-hydrophilic structure. When APH comes in contact with blood, it dries the blood by accelerating the concentration of platelets, red blood cells, and coagulation proteins at the bleeding site and consequently forms a mechanic barrier by turning into gel form. It is hydrolyzed by histamine and degraded to amylase and glucoamylase and then completely resorbed. Clinically, MPHs have produced very successful results in endoscopic nasal sinus surgery, ${ }^{[9]}$ dermatologic surgery, ${ }^{[10,11]}$ and laparoscopic surgery, causing no serious complications intra- and postoperatively. ${ }^{[12]}$ Formerly, the hemostatic agent APH has not been used against bleeding of tissue defect in patients under anticoagulant therapy. This study aimed to determine the efficacy and reliability of this agent in hemostasis in rats pretreated with warfarin.

\section{MATERIALS AND METHODS}

\section{Experimental Model}

Forty-eight adult male Wistar albino rats weighing between 250-300 g were randomly selected from our animal research center. The rats were randomized into six experimental groups of eight rats each, with sample sizes for attaining 0.9 power at $95 \%$ significance level. They were kept at a constant temperature $\left(22 \pm 1^{\circ} \mathrm{C}\right)$ under a $12 \mathrm{~h}$ light/dark cycle. The animals were supplied with standard laboratory pellet diet and water ad libitum. All experimental procedures were elaborately evaluated and approved by the Bezmialem Local Research Ethics Committee.

\section{Experimental Design}

Rats were randomly divided into two main groups as seen Table I. The back regions of all animals in both groups were shaved and cleaned with povidone-iodine. The first group $(n=24)$ did not receive any treatment. The second group $(n=24)$ were treated with warfarin $(2 \mathrm{mg} / \mathrm{kg})$ dissolved in isotonic solution through oral feeding catheter daily for four days. International Normalized Ratio (INR) was assessed with INR monitoring systems (INRatio ${ }^{\circledR}$; Hemosense, Calif) prior to and on the fifth day of warfarin treatment. INR value above 2 was accepted as adequate anticoagulation. All groups was further divided into three subgroups-A, B and $C$ (eight rats per group) and animals were numbered from I to 8 as shown in Table I. In order to administer to the sites of tissue defects of subgroups, $4 \mathrm{~mL}$ saline were prepared by injector for subgroup A; $3 \mathrm{mg}$ APH in powdery form (HaemoCer ${ }^{\mathrm{TM}}$, Germany) were prepared for subgroup B; and wheat meal, which was similar in appearance and measurement of particle size to APH by light microscopy, was prepared for subgroup $\mathrm{C}$ on numbered paper sheets (Figure I). Tare weights of numbered papers were determined on a precision scale, and then agents were weighed. On the fifth day, the rats were anesthetized with intraperitoneal $30 \mathrm{mg} / \mathrm{kg}$ ketamine hydro-

Table I. Study groups

\begin{tabular}{lccccc}
\hline Groups & Subgroups* & $\mathbf{n}$ & $\begin{array}{c}\text { Daily } \\
\mathbf{( m g / k g})\end{array}$ & $\begin{array}{c}\text { Method of drug } \\
\text { administration }\end{array}$ & $\begin{array}{c}\text { Duration of drug } \\
\text { administration }\end{array}$ \\
\hline Without warfarin pretreatment & A & 8 & - & - & - \\
With warfarin pretreatment & B & 8 & - & - & - \\
& C & 8 & - & - & - \\
& A & 8 & 2 & Orally & 4 days \\
& B & 8 & 2 & Orally & 4 days \\
\hline
\end{tabular}

\footnotetext{
*: Agents applied to bleeding area. A: $0.9 \%$ saline; B: APH; C: Wheat meal.
} 


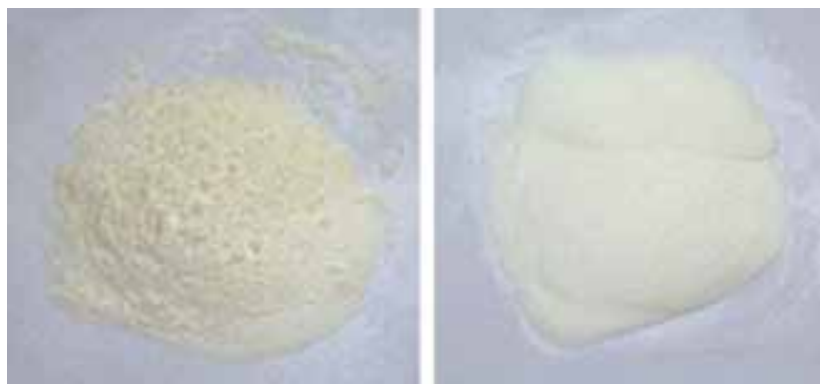

Figure 1. APH and wheat meal appear macroscopically similar on the blotting paper. Particle size on the light microscope are close to each other.

chloride (Ketalar; Eczacibasi, Istanbul, Turkey) and $5 \mathrm{mg} / \mathrm{kg}$ xylazine (Rompun, $2 \%$ solution; Bayer, Germany). The middle of a piece of cardboard was cut out in the shape of an equilateral triangle of size $2 \times 2 \times 2 \mathrm{~cm}$ to make a pattern. Equilateral triangles were drawn on the back of rats using this pattern. Then full thickness tissue defects were performed by cutting skin with scissors.

\section{Evaluation}

We waited to see precise bleeding after incision for one minute in all rats. Afterwards, the prepared materials were administered to the defect sites on the numbered animals by a laboratory technician who did not know the material on numbered papers. Then the defect sites were gently covered with sterile sponge, which were wetted with $20 \mathrm{~mL}$ of $0.9 \%$ saline, for one minute. The wet sponges were removed and bleeding time was monitored. The bleeding time was defined as the time between the removal of the sponge and hemostasis, and was monitored with a chronometer. The amount of bleeding was calculated using the weights of the numbered blotting papers that absorbed the blood in the defect site. Tare weights of these numbered papers were determined on a precision scale. Bleeding time and amount of bleeding were blindly measured by a laboratory technician.

\section{Data Analysis}

Statistical analyses were conducted using IBM SPSS for Windows, version 19.0. Hemostasis time and amount of bleeding of the three subgroups were compared using one way ANOVA with Tukey HSD posthoc comparisons. The mean and standard deviation were calculated for each group. All data were expressed as means and $95 \%$ confidence intervals and $p$ value of 0.005 or less was considered statistically significant.

\section{RESULTS}

The rats were pretreated with warfarin for four days. INR values were measured before and on the fifth day of warfarin treatment. The INR values found were above 2 , as seen in Table 2.

\section{Bleeding time}

The agents were administered after creation of full thickness tissue defect and observation of bleeding within one minute. It was observed that APH showed an effective hemostatic efficiency by forming a thick layer of gel very quickly, as seen Figure $2 \mathrm{a}$, b.

In groups that were not pretreated with warfarin, the bleeding time was 1.20 minutes $(95 \% \mathrm{Cl}$ I.04-I.36) in the saline administered subgroup, 0.58 minutes $(95 \% \mathrm{Cl} 0.44-0.73)$ in the wheat meal administered subgroup, and 0.15 minute $(95 \% \mathrm{Cl} 0.12-$ 0.18 ) in the APH administered subgroup. APH reduced the duration of bleeding in the non-pretreated group by $87.50 \%$ compared to saline-administered group, and 74.13\% compared to wheat meal administered group $(p<0.001)$ (See Table 3).

In groups pretreated with warfarin, the bleeding time was 3.61 minutes $(95 \% \mathrm{Cl} 2.82-4.40)$ in the saline administered subgroup, 2.40 minutes $(95 \% \mathrm{Cl} \mathrm{I,86-2,94)}$ in the wheat meal administered subgroup, and 0.38 minute $(95 \% \mathrm{Cl} 0.16-0.60)$ in the APH administered subgroup. APH reduced the duration of bleeding in pretreated group by $89.48 \%$ compared to the saline administered group, and $84.1 \%$ compared to the wheat meal administered group $(p<0.001)$ (Table 3$)$.

\section{Amount of Bleeding}

$\mathrm{APH}$ reduced both the bleeding time and amount. In the groups not pretreated with warfarin, the amount of bleeding was $0.11 \mathrm{~mL}(95 \% \mathrm{Cl} 0.10-0.13)$ in the saline administered subgroup, $0.06 \mathrm{~mL}(95 \% \mathrm{Cl} 0.05-0.07)$ in the wheat meal administered subgroup, and $0.04 \mathrm{~mL}(95 \% \mathrm{Cl} 0.03-0.05)$ in the APH subgroup. APH reduced the amount of bleeding in nonpretreated group by $63.63 \%$ compared to saline administered group, and $33.33 \%$ compared to wheat meal administered group $(p<0.00 \mathrm{I})$ (Table 3$)$.

Table 2. INR values

\begin{tabular}{|c|c|c|c|c|c|c|}
\hline & \multicolumn{3}{|c|}{$\begin{array}{c}\text { Without } \\
\text { pretreatment }\end{array}$} & \multicolumn{3}{|c|}{$\begin{array}{l}\text { Under warfarin } \\
\text { pretreatment }^{*}\end{array}$} \\
\hline & A & B & C & A & B & C \\
\hline I & 0.9 & I.I & 1.2 & 5.6 & 7.5 & 2.7 \\
\hline 2 & 1.2 & 1.2 & I.I & 2.7 & 4.5 & 2.1 \\
\hline 3 & 1.2 & 1.3 & 1.2 & 2.4 & 3.2 & 4.5 \\
\hline 4 & 0.8 & I.I & 0.8 & 2.1 & 5.2 & 7.5 \\
\hline 5 & I.I & I.I & 1.2 & 5.6 & 2.4 & 2.2 \\
\hline 6 & 1.2 & I.I & 1.3 & 2.1 & 7.5 & 3.9 \\
\hline 7 & 1.2 & 1.0 & 1.3 & 4.8 & 4.8 & 2.2 \\
\hline 8 & I.I & 1.3 & 1.2 & 2.4 & 2. 1 & 2.4 \\
\hline
\end{tabular}



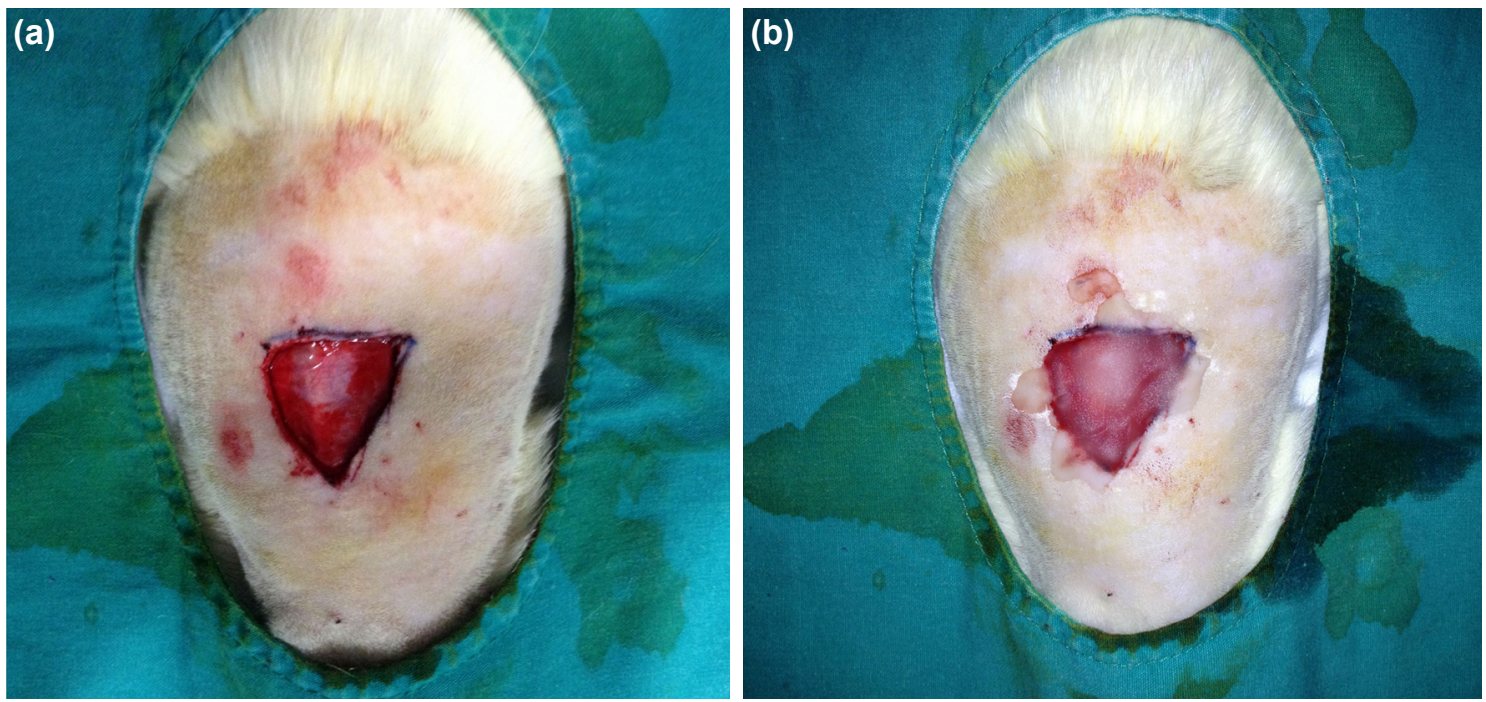

Figure 2. (a) Triangular-shaped full-thickness cut was made by surgical scissors, and bleeding became clear in one minute. (b) APH applied to the tissue defect after bleeding clarified. We cushioned gently with a wet sponge for one minute. Hemostasis was provided in 20 seconds after the sponge moved away.

In groups pretreated with warfarin, the amount of bleeding was $0.34 \mathrm{~mL}(95 \% \mathrm{Cl} 0.23-0.45)$ in the saline administered subgroup, $0.25 \mathrm{~mL}(95 \% \mathrm{Cl} 0.19-0.3 \mathrm{I})$ in the wheat meal administered subgroup, and $0.05 \mathrm{~mL}(95 \% \mathrm{Cl} 0.03-0.07)$ in the APH subgroup. APH reduced the amount of bleeding in pretreated group by $85.30 \%$ compared to saline administered

Table 3. Duration and amount of bleeding for each agent applied, relative statistical meanings and percentages

\begin{tabular}{|c|c|c|c|c|c|c|c|c|}
\hline & \multicolumn{8}{|c|}{$95 \%$ Confidence interval for mean } \\
\hline & $\begin{array}{l}\text { Group } \\
\left(n_{i}=8\right)\end{array}$ & Mean & $\begin{array}{c}\text { Std. } \\
\text { deviation }\end{array}$ & $\begin{array}{l}\text { Lower } \\
\text { bound }\end{array}$ & $\begin{array}{l}\text { Upper } \\
\text { bound }\end{array}$ & ANOVA & APH vs. $\%$ & $\begin{array}{l}\text { Controls } \\
\text { decrease }\end{array}$ \\
\hline \multirow{5}{*}{$\begin{array}{l}\text { Duration of } \\
\text { bleeding without } \\
\text { warfarin } \\
\text { pretreatment } \\
\text { (min) }\end{array}$} & A & 1.20 & 0.19 & 1.04 & 1.36 & $\mathrm{~F}=99.1 \mathrm{I}$ & - & - \\
\hline & & & & & & $p=0.001$ & B vs. A & 87.50 \\
\hline & B & 0.15 & 0.03 & 0.12 & 0.18 & (tukeyHSD: & B vs. C & 74.13 \\
\hline & & & & & & all groups) & C vs. A & \\
\hline & C & 0.58 & 0.17 & 0.44 & 0.73 & & & 51.66 \\
\hline \multirow{6}{*}{$\begin{array}{l}\text { Amount of } \\
\text { bleeding } \\
\text { without } \\
\text { warfarin } \\
\text { pretreatment } \\
(\mathrm{ml})\end{array}$} & A & 0.11 & 0.02 & 0.10 & 0.13 & $\mathrm{~F}=60.91$ & - & - \\
\hline & & & & & & $p=0.001$ & B vs. A & 63.63 \\
\hline & B & 0.04 & 0.01 & 0.03 & 0.05 & (tukeyHSD: & B vs. C & 33.33 \\
\hline & & & & & & all groups) & & \\
\hline & & & & & & & & \\
\hline & C & 0.06 & 0.01 & 0.05 & 0.07 & & C vs. A & 45.45 \\
\hline \multirow{5}{*}{$\begin{array}{l}\text { Duration of } \\
\text { bleeding } \\
\text { with } \\
\text { warfarin } \\
\text { pretreatment }\end{array}$} & A & 3.61 & 0.94 & 2.82 & 4.40 & $\mathrm{~F}=46.6 \mathrm{I}$ & - & - \\
\hline & & & & & & $p=0.001$ & B vs. A & 89.48 \\
\hline & B & 0.38 & 0.27 & 0.16 & 0.60 & (tukeyHSD: & B vs. C & 84.17 \\
\hline & & & & & & all groups) & & \\
\hline & & & & & & & & \\
\hline$(\min )$ & C & 2.40 & 0.64 & 1.86 & 2.94 & & C vs. A & 33.52 \\
\hline \multirow{6}{*}{$\begin{array}{l}\text { Amount of } \\
\text { bleeding } \\
\text { with } \\
\text { warfarin } \\
\text { pretreatment } \\
(\mathrm{ml})\end{array}$} & A & 0.34 & 0.13 & 0.23 & 0.45 & $F=22.64$ & - & - \\
\hline & & & & & & $p=0.001$ & & \\
\hline & B & 0.05 & 0.02 & 0.03 & 0.07 & (tukeyHSD: & B vs. A & 85.30 \\
\hline & & & & & & B vs $A C)$ & B vs. C & 80.00 \\
\hline & & & & & & & & \\
\hline & C & 0.25 & 0.07 & 0.19 & 0.31 & & C vs. A & 26.48 \\
\hline
\end{tabular}


group, and $80.00 \%$ compared to wheat meal administered group $(\mathrm{p}<0.00 \mathrm{I})$ (Table 3$)$.

\section{DISCUSSION}

In this study, we evaluated the in vivo effect of $\mathrm{APH}$, a hemostatic agent of plant origin, on the bleeding of skin defects in rats pretreated and non-pretreated with warfarin. The results of the study showed that APH was an effective hemostatic, reducing the bleeding time and amount in rats on and not on anticoagulant therapy.

Warfarin has been used successfully in cases requiring longtime anticoagulation, such as atrial fibrillation, history of stroke, history of deep venous thrombosis or pulmonary embolism, valvular heart disease, presence of a mechanical heart valve, and underlying hypercoagulopathy. ${ }^{\left[{ }^{13]}\right]}$ If warfarin therapy is stopped, it takes about four days to reduce INR to I.5 in order to perform the operation safely, ${ }^{[14]}$ and if warfarin therapy is restarted, it takes about three days to reach 2.0 of INR. ${ }^{[15]}$ Our study was performed on rats with INR over 2.0 (Table 2). If warfarin therapy is stopped for four days before surgery and is started as soon as possible following surgery, it means that INR values will be below therapeutic dosages for two days before surgery and two days after surgery, which means that patients would have minimal protection against thromboembolism. ${ }^{[13]}$ This risk exists even in the absence of anticoagulation therapy one day before and one day after surgery. ${ }^{[16]}$ Regardless of the approach to perioperative anticoagulation used, patients need to have a normal or nearly-normal state of coagulation during surgery, so the risk of thromboembolism is unavoidable. Since stopping anticoagulation can lead to life-threatening complications, therapy should not stop abruptly.

Approximately 1.5-3.7\% of patients on warfarin therapy undergo a cutaneous surgery. According to the studies, although warfarin therapy is stopped for patients in $80 \%$ of cutaneous surgeries, heparin is not administered as bridging therapy for $90 \%$ of these patients. ${ }^{[16]}$ It is widely accepted that the risk of bleeding is low in patients taking warfarin during and after minor cutaneous surgery, and bleeding is easy to control. Alcalay ${ }^{[17]}$ reviewed the intraoperative and postoperative bleedings for 16 patients on warfarin therapy. There were 14 cases with lesions of the head and neck region, II cases with Mohs' excisions, and 5 cases with excisional surgery. The measured INR values of patients with bleedings were 3.0 in 4 patients and above 2.0 in 6 patients a week prior to surgery. A group of patients on warfarin who underwent surgery on the same days served as the control group. There was no significant difference between test and control group in terms of intraoperative and postoperative bleedings.

Billingsley and Maloney ${ }^{[16]}$ studied the relation of preoperative warfarin use to intraoperative bleedings, need for dressing changes, and other postoperative procedures. In this study,
332 patients underwent cutaneous Mohs' surgery and were examined; $3.6 \%$ of these patients had taken warfarin within two days before surgery. Intraoperative bleedings which took longer than three minutes to control were related to warfarin use. Although intraoperative bleedings were severe in 5 of the 12 patients on warfarin, no serious problem requiring early dressing change, frequent visits or having surgery again, were reported in the postoperative period. There was no statistical difference between patients who were or were not on warfarin therapy. According to these results, warfarin use can cause intraoperative complications, but cause no complications in the postoperative period. Bordeaux et al. ${ }^{[18]}$ supported that warfarin use significantly increased the risk of bleeding $(p<0.001)$. In their prospective study, Syed et al. ${ }^{[19]}$ reported that there was more bleeding in patients on warfarin therapy when compared with the controls in cutaneous surgery. In our study, warfarin use in the control group increased the bleeding time from I.20 minutes to $3.6 \mathrm{I}$ minutes and increased the amount of bleeding from $0.11 \mathrm{mg}$ to 0.34 ; although these values were found to be highly significant, they did not cause life-threatening problems.

On the other hand, there exist studies on complications of serious bleeding. In their prospective study of 102 patients, Kargi et al. ${ }^{[20]}$ investigated the effect of warfarin in minor surgeries and showed that warfarin use was a risk factor for persistent bleeding, hematoma, or graft/flap infection. All of these studies underline that although warfarin prolongs the bleeding time, stopping warfarin therapy causes life-threatening risks; physicians approach these patients carefully, but should not withhold the drug. However, prolonged bleedingtime can cause stress both for the surgeon and the patient. In such a situation, the surgeon has to make a choice: he would either accept a theoretically-higher likelihood of bleeding and the patient would be anticoagulated, or take the risk of thromboembolism by stopping the anticoagulant therapy. The decision is often postponed and deferred to the caretakers. Caretakers often make a decision without previously being informed in detail on bleeding complications or seriousness of the complications. Studies have shown that many surgical procedures can be safely performed without stopping anticoagulation therapy. Surgeons can choose to operate without discontinuing anticoagulant therapy and can avoid potentially life-threatening thromboembolic complications. ${ }^{[13]}$

The paradox of the surgeon is to sustain blood flow in the whole body while avoiding problems caused by this flow at the surgery site. For this very reason, hemostatic properties of adjuvant therapy methods without hindering normal blood flow are of the utmost importance.

The control of apparent bleeding is performed primarily using mechanical means such as manual pressure, ligature, or application of a tourniquet. However, these methods can sometimes be labor-intensive and time-consuming. Bleeding 
vessels can be interfered with electro-cauterization or laser cauterization. However, these methods constitute a necrotic tissue, burning the vessels with the surrounding tissue, and can cause a delay in wound healing by incurring an infection. [10] Conventional methods are also less effective in controlling bleeding from complex lesions and where access to the bleeding site is difficult. In such situations, use of topical hemostatic agents is recommended. ${ }^{[8]}$

Currently, hemostatic agents are used in a wide-range of surgical interventions and have been reported by many authors as effective in controlling bleeding. For example, the direct application of absorbable hemospheres on superficial cerebral hemorrhage helped to stop bleeding and reduced the use of electrocautery, and thus shortened the surgical time in neurosurgery. ${ }^{[22]}$ In a controlled study comparing the bleeding time in incisions, it was shown that $\mathrm{MPH}$ significantly reduced the time to hemostasis. For many incisions of $5 \times 1 \mathrm{~mm}$ examined in the study, no relevance of the incision method to the bleeding time was found. ${ }^{[8]}$ In cases of prolonged puncturesite bleeding in patients receiving hemodialysis, MPH technology was thought to reduce the normal average bleeding time of 35 minutes to 5 minutes. ${ }^{[23]}$ In our study, bleeding time in rats non-pretreated with warfarin was 1.20 minutes in the saline administered subgroup, 0.58 minutes in the wheat meal administered subgroup, and 0.15 minutes in the APH administered subgroup. There was a significant statistical difference between APH and the other subgroups as to bleeding time $(p<0.00 \mathrm{I})$. MPH technology provides fast and effective hemostasis in endoscopic nasal sinus surgeries, ${ }^{[9]}$ dermatologic surgeries, ${ }^{[1]}$ and laparoscopic surgeries ${ }^{[12]}$ with no serious sideeffects or postoperative complications. With the increase of minimally-invasive surgical procedures with risks of bleeding, the importance of topical hemostats has also increased. ${ }^{[8]}$

Hemostatics provide quite successful results in patients not receiving anticoagulants, but there are only a few studies on their effects on patients on warfarin therapy. The Syvek Patch, a polysaccharide, can be used in patients on anticoagulant therapy for the control of bleedings at vascular access site punctures, percutaneous catheter or tube sites, and surgical debridement sites. ${ }^{[24]}$ King et al. ${ }^{[25]}$ observed 10 hypothermic and coagulopathic trauma patients with severe visceral injuries who failed in conventional treatments. The authors showed that the application of MRDH (Modified Rapid Deployment Hemostat) stopped bleeding in these patients. In our study, bleeding time in the control group on warfarin therapy was $3.6 \mathrm{I}$ minutes in the saline administered subgroup, 2.40 minutes in the wheat meal administered subgroup and 0.38 minutes in the APH administered subgroup. The hemostatic effect of APH was apparent when compared with those of the control groups. Although no life-threatening problem exists in cases of prolonged bleeding-time due to anticoagulants, it is evident that APH effectively reduces the bleeding time and also the stress of the surgeons and patients in elective and emergency surgery.

\section{Conclusion}

$\mathrm{APH}$ is an effective hemostatic agent in rats pretreated with anticoagulants. This agent could be an effective hemostatic in patients in plastic surgery and dermatology clinics and in patients with tissue defect applying to emergency centers, and could also raise the self-confidence of the surgeon. The hemostatic effect of APH should be investigated further in larger and more severe tissue injuries.

\section{Acknowledgements}

All the authors of this article have no financial or personal relationship with any of the companies mentioned in the text.

\section{REFERENCES}

1. Phillips S, Barr A, Wilson E, Rockall TA, Stebbing JF. Two cases of retroperitoneal haematoma caused by interaction between antibiotics and warfarin. Emerg Med J 2006;23:e8.

2. Eijgenraam P, ten Cate H, Ten Cate-Hoek A. Safety and efficacy of bridging with low molecular weight heparins: a systematic review and partial meta-analysis. Curr Pharm Des 2013;19:4014-23.

3. Shetty HG, Backhouse G, Bentley DP, Routledge PA. Effective reversal of warfarin-induced excessive anticoagulation with low dose vitamin K1. Thromb Haemost 1992;67:13-5.

4. Thumboo J, O'Duffy JD. A prospective study of the safety of joint and soft tissue aspirations and injections in patients taking warfarin sodium. Arthritis Rheum 1998;41:736-9.

5. Dunn AS, Turpie AG. Perioperative management of patients receiving oral anticoagulants: a systematic review. Arch Intern Med 2003;163:901-8.

6. Eisen GM, Baron TH, Dominitz JA, Faigel DO, Goldstein JL, Johanson JF, Mallery JS, et al. Guideline on the management of anticoagulation and antiplatelet therapy for endoscopic procedures. Gastrointest Endosc 2002;55:775-9.

7. Levy JH. Hemostatic agents. Transfusion 2004;44(12 Suppl):58S-62S.

8. Seyednejad H, Imani M, Jamieson T, Seifalian AM. Topical haemostatic agents. Br J Surg 2008;95:1197-225.

9. Antisdel JL, West-Denning JL, Sindwani R. Effect of microporous polysaccharide hemospheres (MPH) on bleeding after endoscopic sinus surgery: randomized controlled study. Otolaryngol Head Neck Surg 2009; 141:353-7.

10. Tan SR, Tope WD. Effectiveness of microporous polysaccharide hemospheres for achieving hemostasis in mohs micrographic surgery. Dermatol Surg 2004;30:908-14.

11. Ho J, Hruza G. Hydrophilic polymers with potassium salt and microporous polysaccharides for use as hemostatic agents. Dermatol Surg 2007;33:1430-3.

12. Humphreys MR, Castle EP, Andrews PE, Gettman MT, Ereth MH. Microporous polysaccharide hemospheres for management of laparoscopic trocar injury to the spleen. Am J Surg 2008;195:99-103.

13. Adjusted-dose warfarin versus low-intensity, fixed-dose warfarin plus aspirin for high-risk patients with atrial fibrillation: Stroke Prevention in Atrial Fibrillation III randomised clinical trial. Lancet 1996;348:633-8.

14. White RH, McKittrick T, Hutchinson R, Twitchell J. Temporary discontinuation of warfarin therapy: changes in the international normalized ratio. Ann Intern Med 1995;122:40-2.

15. Harrison L, Johnston M, Massicotte MP, Crowther M, Moffat K, Hirsh J. Comparison of 5-mg and 10-mg loading doses in initiation of warfarin 
therapy. Ann Intern Med 1997;126:133-6.

16. Billingsley EM, Maloney ME. Intraoperative and postoperative bleeding problems in patients taking warfarin, aspirin, and nonsteroidal antiinflammatory agents. A prospective study. Dermatol Surg 1997;23:381-5.

17. Alcalay J. Cutaneous surgery in patients receiving warfarin therapy. Dermatol Surg 2001;27:756-8.

18. Bordeaux JS, Martires KJ, Goldberg D, Pattee SF, Fu P, Maloney ME. Prospective evaluation of dermatologic surgery complications including patients on multiple antiplatelet and anticoagulant medications. J Am Acad Dermatol 2011;65:576-83.

19. Syed S, Adams BB, Liao W, Pipitone M, Gloster H. A prospective assessment of bleeding and international normalized ratio in warfarinanticoagulated patients having cutaneous surgery. J Am Acad Dermatol 2004;51:955-7.

20. Kargi E, Babuccu O, Hosnuter M, Babuccu B, Altinyazar C. Complications of minor cutaneous surgery in patients under anticoagulant treat- ment. Aesthetic Plast Surg 2002;26:483-5.

21. Zwischenberger JB, Brunston RL Jr, Swann JR, Conti VR. Comparison of two topical collagen-based hemostatic sponges during cardiothoracic procedures. J Invest Surg 1999;12:101-6.

22. Galarza M, Porcar OP, Gazzeri R, Martínez-Lage JF. Microporous Polysaccharide Hemospheres (MPH) for cerebral hemostasis: a preliminary report. World Neurosurg 2011;75:491-4.

23. Ahmed Z, Lee J, Elivera H, Shah A, Ranganna KM. Use of microporous polysaccharide particles in prolonged vascular access bleeding after hemodialysis. Presented to the American Society of Nephrology, 1 November 2002; http://www.medaforinc.com/research/index.html [Accessed 12 September 2007].

24. Hirsch JA, Reddy SA, Capasso WE, Linfante I. Non-invasive hemostatic closure devices: "patches and pads". Tech Vasc Interv Radiol 2003;6:92-5.

25. King DR, Cohn SM, Proctor KG; Miami Clinical Trials Group. Modified rapid deployment hemostat bandage terminates bleeding in coagulopathic patients with severe visceral injuries. J Trauma 2004;57:756-9.

\title{
DENEYSEL ÇALIŞMA - ÖZET
}

\section{Hemostatik bir ajanın antikoagülan ilaç alan sıçan kanama modelindeki etkinliği \\ Dr. Ertan Sönmez, ${ }^{1}$ Dr. Umut Yücel Çavuş, ${ }^{3}$ Dr. Cemil Civelek, ${ }^{1}$ Dr. Ali Dur, ${ }^{1}$ \\ Dr. Eda Karayel, ${ }^{1}$ Dr. Bedia Gülen, ${ }^{1}$ Dr. Ömer Uysal, ${ }^{2}$ Dr. Göktürk Ijpek ${ }^{4}$}

\begin{abstract}
${ }^{1}$ Bezmialem Vakıf Üniversitesi Tıp Fakültesi, Acil Tıp Anabilim Dalı, İstanbul;
${ }^{2}$ Bezmialem Vakıf Üniversitesi Tıp Fakültesi, Biyoistatistik Anabilim Dalı, İstanbul;

${ }^{3}$ Dışkapı Yıldırım Beyazıt Eğitim ve Araştırma Hastanesi, Acil Tıp Kliniği, Ankara;

${ }^{4}$ Siyami Ersek Eğitim ve Araştırma Hastanesi, Kardiyoloji Kliniği, İstanbul
\end{abstract}

AMAÇ: Varfarin ile tedavi edilen hastalarda özellikle acil cerrahi işlem gerektiğinde kanama önemli bir problemdir. APH ultra-hidrofilik ve toz halinde bir kanama durdurucu ajandır. Bu çalı̧̧ada, APH'nin varfarin alan sıçanlardaki kanama durdurucu etkisi araştırıldı.

GEREÇ VE YÖNTEM: Kırk sekiz Wistar sıçan iki ana guruba ayrıldı. Bir gurup varfarin ile tedavi edilirken diğerine verilmedi. Bu iki gurup daha sonra üç altguruba bölündü. Birine APH, birine buğday unu ve birine de serum fizyolojik uygulanmak üzere toplam altı gurup yapıldı. Sıçanların sırtında standart tam kat doku defekti oluşturuldu. Her iki ana guruba da serum fizyolojik, buğday unu veya APH uygulandı. Kanama zamanı ve kanama miktarları hesaplandı.

BULGULAR: APH uygulananlarda, serum fizyolojik veya buğday unu uygulananlara göre kanama zamanı önemli derecede kısa ve kanama miktarları oldukça az bulundu.

TARTIŞMA: APH antikoagülan tedavi alan veya almayan sıçanlarda etkili bir kanama durdurucudur. Kanama durdurucu ajanlar antikoagülasyona bağlı artmış dış kanamalarda kullanılabilir.

Anahtar sözcükler: Hemostatik; sıçan; varfarin.

Ulus Travma Acil Cerr Derg 2014;20(2):79-85 doi: 10.5505/tjtes.20I4.54938 